\title{
Antioxidant Activity, Polyphenols Content and Antimicrobial Activity of Several Native Pteridophytes of Romania
}

\author{
Liliana Cristina SOARE1,2, Mariana FERDEŞ², Stefan STEFANOV², Zapriana DENKOVA ${ }^{3}$ \\ Radosveta NICOLOVA ${ }^{3}$, Petko DENEV ${ }^{4}$, Carmen BEJAN ${ }^{5}$, Alina PĂUNESCU ${ }^{6}$ \\ ${ }^{1}$ University of Agricultural Sciences and Veterinary Medicine Cluj-Napoca, 3 Mănăşstur Street, Cluj-Napoca, Romania \\ ${ }^{2}$ Politehnica University of Bucharest, Faculty of Medical Engeneering, Department of Bioengineering and \\ Biotechnology, 313 Splaiul Independenței,060042,Bucharest; soleil_cri@yahoo.com \\ ${ }^{3}$ University of Food Technology, Technical Faculty, 26 Maritza Boulevard, 4002 Plovdiv, Bulgaria \\ ${ }^{4}$ Institute of Organic Chemistry with Centre of Phytochemistry-BAS, Laboratory of Biologicaly \\ Active Substances, 95 Vasil Aprilov Boulevard, 4002 Plovdiv, Bulgaria \\ ${ }^{5}$ National Institute of Research and Development for Bio-Technologies in Horticulture, Ştefăneşti, Argeş, Romania \\ ${ }^{6}$ University of Pitești, 1 Târgul din Vale Street, 110040 Pitești, Argeș, Romania
}

\begin{abstract}
The aim of this paper was to test the antioxidant activity, polyphenols content and antimicrobial activity of crude extracts obtained from leaves of pteridophyte species commonly found in Romania. The ORAC (Oxygen Radical Absorbance Capacity) of the investigated ferns varied between $421.90 \mu \mathrm{mol}$ TE (Trolox equivalents/g FW (fresh weight) in Dryopteris flix-mas and $128.18 \mu \mathrm{mol} \mathrm{TE} / \mathrm{g} \mathrm{FW}$ in $D$. affinis. Methanolic extracts obtained from leaves of ferns have similar antioxidant activity to that of some medicinal plants. Polyphenols content in the leaves of ferns varies between $2340 \mathrm{mg}$ Gallic acid equivalents (GAE)/100 g FW in D. filix-mas and $887 \mathrm{mg}$ GAE/100 g FW in $D$. affinis. The correlation coefficient between ORAC and the total polyphenol content was $\mathrm{R}=0.985$. This correlation suggests that phenolic compounds are major contributors to the antioxidant activity. The methanolic extract obtained from ferns inhibits the growth of Gram negative Escherichia coli ATCC 25922, Pseudomonas aeruginosa NBJMCC1390, Salmonella abony and Gram positive Staphyllococcus aureus ATCC 25093 and Enterococcus faecalis. The highest antimicrobial activity was determined for the Dryopteris extract. The antimicrobial activity of methanolic extracts obtained from leaves of $D$. filix-mas and $D$. affinis is better than the $A$. filix-femina in the case of Brevibacterium flavum ATCC 14067, Sarcina sp., Bacillus cereus ATCC 1390, Saccharomyces cerevisiae and Aspergillus niger. The tested ferns could be used as cosmetic ingredients, as preservatives in food or in antimicrobial therapy.
\end{abstract}

Keywords: Athyrium filix-femina, Dryopteris affinis, Dryopteris flix-mas, leaves, microorganism, pathogen, saprophyte

\section{Introduction}

The Ayurvedic systems of medicine recommended the medicinal use of the pteridophytes. Ferns are also used in the Unani system of medicine (Uddin et al., 1998). In China, about 300 kinds of ferns were used as traditional medicinal herbs. In addition to their antioxidant activity, the ferns showed bioactivities such as antimicrobial, antiviral, antiinflammatory, antitussive, antitumor and anti-Human Immunodeficiency Virus (Chang et al., 2011). Efficient antioxidant properties of several ferns such as Davallia, Hypolepis, Pteridium, Cytominum, Dryopteris, Polystichum, Dicranopteris, Lycopodium, Osmunda, Adiatum, Coniogramme, Polypodium, Pyrrosia, Pteris, Lygodium, Selaginella, Thelypteris, Athyrium, Matteuccia, Onoclea and Woodsia were reported (Shin, 2010). Dryopteridaceae, Osmundaceae and Woodsiaceae exhibit powerful antioxi- dant activities. Some crude extracts obtained from ferns showed powerful antioxidant activities, more powerful than those of vitamin C. Analyzing antioxidant activities in many ferns will result in the development of healthcare products for aging and chronic diseases due to their high bioactivities. The extracts obtained from pteridophytes have effective antimicrobial activities against Gram positive bacteria (Staphylococcus aureus, Bacillus subtilis), Gram negative bacteria (Escherichia coli, Salmonella typhi, Pseudomonas aeruginosa), as well as fungi. They could be developed into antibiotic sprays, packing material, toothpaste, hand wash, etc. for the protection of the human body and our living environment against undesirable microbials (Lee and Shin, 2011).

The Romanian flora includes 70 pteridophytes and of these, only a few are used as medicinal plants (Ciocârlan, 2009). The aim of this paper was to test the polyphenols 
54

contents, antioxidant and antimicrobial activity of crude extracts obtained from leaves of pteridophyte species commonly found in Romania to find new resources useful in therapy, cosmetics, food technology, etc.

\section{Materials and methods}

\section{Plants}

Leaf extracts were obtained from Athyrium filix-femina (L.) Roth (Lady Fern), Dryopteris affinis (Lowe) FraserJenkins (Male Fern) and Dryopteris filix-mas (L.) Schott (Male Fern). The plants were colected in May 2011 from the Vâlsan Valley (Argeş county, Romania).

\section{Extraction}

Five grams of fresh leaves were washed with tap water and distilled water and then their surface was sterilized with $90 \%$ ethanol. Subsequently, the plant materials were immersed in $50 \mathrm{ml}$ of methanol for alcoholic extracts. The methanolic macerates were kept for $24 \mathrm{~h}$ at room temperature. Macerates were squeezed through double-layered muslin cloth and filtered through filter paper. After filtration, aliquot was centrifuged at $6000 \mathrm{rpm}$ for $20 \mathrm{~min}$ at room temperature. The supernatants were filtered through Whatman No.1 filter paper.

\section{Oxygen Radical Absorbance Capacity (ORAC)}

ORAC assay was measured according to the method of Ou et al. (2001) with some modifications. The method measures the antioxidant scavenging activity against peroxyl radical induced by 2,2 '-azobis (2-amidinopropane) dihydrochloride $(\mathrm{AAPH})$ at $37^{\circ} \mathrm{C}$. Fluorescein $(\mathrm{FL})$ was used as the fluorescent probe. The loss of fluorescence of FL was an indication of the extent of damage from its reaction with the peroxyl radical. The protective effect of an antioxidant was measured by assessing the area under the fluorescence decay curve (AUC) as compared to the blank area in which no antioxidant is present. Solutions of AAPH, FL and Trolox were prepared in a phosphate buffer $(75 \mathrm{mmol} / 1$, pH 7.4). Samples were diluted in phosphate buffer as well. Reaction mixture (total volume 200 $\mu l)$ contained FL- $\left(170 \mu \mathrm{l}\right.$, final concentration $5.36 \times 10^{-8}$ $\mathrm{mol} / \mathrm{l})$, AAPH-(20 $\mu \mathrm{l}$, final concentration $51.51 \mathrm{mmol} / \mathrm{l})$, and sample $(10 \mu \mathrm{l})$. FL solution and sample were incubated at $37^{\circ} \mathrm{C}$ for $20 \mathrm{~min}$, and AAPH (dissolved in $37^{\circ} \mathrm{C}$ buffer) was added. The mixture was incubated for $30 \mathrm{~s}$ before the initial fluorescence was measured. After that, fluorescence readings were recorded at the end of every cycle after shaking. For the blank, $10 \mu \mathrm{l}$ of phosphate buffer was used instead of a sample. Antioxidant activity was expressed in Trolox equivalents. Trolox solutions (6.25; 12.5; 25; 50 and $100 \mu \mathrm{mol} / \mathrm{l})$ were used for defining the standard curve. One ORAC unit is assigned to the net protection area, provided by a Trolox solution with a concentration of $1 \mu \mathrm{mol} / \mathrm{l}$. The final ORAC values were calculated using a regression equation between the Trolox concentration and the net area under the curve. The antioxidant activity was expressed in micromole Trolox equivalents per gram of fresh weight (FW).

\section{Polyphenols content}

The total polyphenols content was determined according to the method of Singleton and Rosi (1965) with Folin-Ciocalteu reagent. Gallic acid was employed as calibration standard; the results were expressed as Gallic acid equivalents (GAE) per g FW.

\section{Antimicrobial assay}

The antimicrobial activity of crude extracts was tested on 10 microorganism: five pathogen bacteria-Escherichia coli ATCC 25922, Pseudomonas aeruginosa NBJMCC 1390, Salmonella abony, Staphylococcus aureus ATCC 25093 and Enterococcus faecalis, three saprophytic bacteriaBrevibacterium flavum ATCC 14067, Sarcina sp., Bacillus cereus ATCC 1390, one yeast-Saccharomyces cerevisiae and one mould-Aspergillus niger. The bacterial strains were cultivated on LBG Agar medium and the yeast and mould on Malt Agar medium. Plant extracts were tested in three concentrations: undiluted extract, $10^{-1}$ and $10^{-2}$. The disc diffusion assay was used to determine the growth inhibition of microorganisms. Each paper disc was impregnated with $6 \mu \mathrm{l}$ extract. The antimicrobial activity was expressed as the zone of inhibition (IZ) produced by the plant extract. For each extract was established the minimum inhibitory concentration (MIC) (ppm).

\section{Results and discussion}

\section{Antioxidant activity}

The antioxidant activity of fern species was evaluated with different methods, such as: DPPH (1,1-Diphenyl2-picrylhydrazyl) assay, ABTS [2,2'-azino-bis(3-ethylbenzothiazoline-6-sulphonic acid)] assay, FRAP (Ferric reducing ability of plasma) assay, ORAC (The oxygen radical absorbance capacity) assay, TRAP (The total radical trapping parameter) assay, DCFH-DA (Dichlorofluorescin-diacetate)-based assay, Cyclic voltammetry method, TOSC (total oxyradical scavenging capacity) assay, PCL (Photochemiluminescence) assay, Crocin CL test assay (crocin chemoluminescence assay), Chronocoulometric assay, CAA assay (Cellular antioxidant activity), Conjugated diene assay, Superoxide radical scavenging activity, Hydroxyl radical scavenging activity, Nitric oxide radical inhibition activity, Reducing power method, Phospho molybdenum method, Peroxynitrile radical scavenging activity, $\beta$-carotene linoleate method, Xanthine oxidase method, Cytochrome C test, Erythrocyte ghost system Microsomal lipid peroxidation or Thiobarbituric acid (TBA) 
assay (Mubashir and Shah, 2011). The ORAC method is preferred for the measurement of the antioxidant activity of foods and biological samples. Ninfali et al. (2005) performed a comprehensive evaluation of different foods and spices using this method, Wojcikowski et al. (2007) investigated the ORAC antioxidant activity of 55 medicinal plants and Kratchanova et al. (2010) evaluated the ORAC antioxidant activity of 25 medicinal plants of Bulgaria. Tab. 1 shows the ORAC antioxidant activity of the investigated ferns. The antioxidant activity varied between $421.90 \mu \mathrm{mol} \mathrm{TE} / \mathrm{g} \mathrm{FW}$ in Dryopteris filix-mas and 128.18 $\mu \mathrm{mol} \mathrm{TE} / \mathrm{g} \mathrm{FW}$ in $D$. affinis. The antioxidant activity of plants varies by species and within the same species differences were found depending on the solvent extraction, the physical condition of the plant material (fresh or dried) or environmental factors (Kratchanova et al., 2010).

Methanolic extracts obtained from the leaves of three fern species have a similar antioxidant activity to that of some medicinal plants. Thus, close values to those obtained for $D$. filix-mas have been reported in extracts obtained from Calendula officinalis flowers (Marigold) $(407 \mu \mathrm{mol}$ TE/g DW), Ocimum basilicum leaves (Basil) (402 $\mu \mathrm{mol}$ TE/g DW) and Matricaria chamomilla (Chamomile) flowers (469 $\mu \mathrm{mol} \mathrm{TE} / \mathrm{g}$ DW) (Kratchanova et al., 2010). A similar antioxidant activity to that obtained in Athyrium filix-femina $(186.53 \mu \mathrm{mol} \mathrm{TE} / \mathrm{g} \mathrm{FW})$ was reported for aqueous extracts obtained from aerial parts of Taraxacum officinale (Dandelion) (193 TE/g DW) and from leaves of Laurus nobilis (Laurel) $(170 \mu \mathrm{mol}$ TE/g DW). The antioxidant activity determined in D. affinis $(128.18 \mu \mathrm{mol}$ TE/g FW) is close to that reported for Cichorium inthybus (Chicory) (aerial parts, water extraction) (132 $\mu \mathrm{mol}$ $\mathrm{TE} / \mathrm{g}$ DW).

\section{Polyphenols content}

The polyphenols content in the leaves of ferns varies between $887 \mathrm{mg} \mathrm{GAE} / 100 \mathrm{~g} \mathrm{FW}$ in D. affinis and $2340 \mathrm{mg}$ GAE/100 g FW in D. flix-mas (Tab. 2). Zheng and Wang (2001) reported excellent correlation for medicinal plants and culinary herbs when antioxidant activity (determined using the oxygen radical absorbance assay, ORAC assay) was compared with the polyphenols content. A linear correlation between antioxidant activity and the content of polyphenols have been reported by Katalinic et al. (2006), Kiselova et al. (2006), Kratchanova et al. (2010), Maizura et al. (2011) and Vasco et al. (2008). Other authors found no such correlation (Souri et al., 2008).

Tab. 1. ORAC antioxidant activity (mean \pm S.D. in $\mu \mathrm{mol} T E / \mathrm{g}$ $\mathrm{FW}$ ) of the investigated ferns

\begin{tabular}{lcc}
\hline & Sample & ORAC \\
\hline 1 & Athyrium filix-femina & $186.53 \pm 1.52$ \\
2 & Dryopteris affinis & $128.18 \pm 7.37$ \\
3 & Dryopterisfilix-mas & $421.90 \pm 15.14$ \\
\hline
\end{tabular}

In this study, the correlation coefficient between ORAC and the total polyphenols content was $\mathrm{R}=0.985$. This correlation suggests that phenolic compounds are major contributors to the antioxidant activity. Also, RiceEvans et al. (1997), Shan et al. (2005), Wong et al. (2006) and Wu et al. (2006) reported that phenolic compounds in spices and herbs significantly contributed to their antioxidant properties. Cai et al. (2004) showed a linear correlation between antioxidant activity and the total phenolic content in the 112 traditional Chinese medicinal plants associated with anticancer properties. Chang et al. (2007) showed a good correlation between antioxidant capacity and the total polyphenols content in six ferns used in the Chinese system of medicine. Kratchanova et al. (2010) reported a correlation coefficient $R=0.950$ in the case of the water extract of 25 Bulgarian medicinal plants and $R=875$ in the case of acetone extract. A good correlation was demonstrated between the antioxidant activity and the total phenolic compounds in the Labiatae and Asteraceae from Poland (Wojdyło et al., 2007). A positive correlation coefficient between the total phenolic content and DPPH assay of plants extracts obtained from kesum (Polygonum minus), ginger (Zingiber officinale) and turmeric (Curcuma longa) was reported by Maizura et al. (2011).

\section{Antimicrobial activity}

The methanolic extract obtained from ferns inhibits the growth of Gram negative Escherichia coli, Pseudomonas aeruginosa, Salmonella abony and Gram positive Staphyllococcus aureus and Enterococcus faecalis (Tab. 3). The highest antimicrobial activity was determined in Dryopteris filix-mas extract. $60 \mathrm{ppm}$ is the MIC for E. coli, Salmonella abony and Enterococcus faecalis. The same MIC was obtained in D. affinis extract in the case of Salmonella abony and Enterococcus faecalis. A. flix-femina extract has the lowest antimicrobial activity. The highest IZ was determined in the D. affinis extract against Enterococcus fecalis, and the lowest in the A.filix-femina extract against Staphyllococcus aureus and Enterococcus faecalis. The antimicrobial activity of methanolic extracts obtained from leaves of $D$. filixmas and $D$. affinis is better than those of $A$. filix-femina in the case of Brevibacterium flavum, Sarcina sp., Bacillus cereus, Saccharomyces cerevisiae and Aspergillus niger (Tab. 4). Microorganism growth was inhibited by ferns extracts; the IZ was larger than $8 \mathrm{~mm}$ in Dryopteris species extract. Parihar et al. (2010) shows that leaves extract of Athyrium pectinatum inhibited the growth of Salmonella arizonae, but did not inhibit the growth of E. coli, Salmonella typhi

Tab. 2. Polyphenols content (mean \pm S.D. in mg GAE/100 g $\mathrm{FW}$ ) of ferns leaves

\begin{tabular}{lcc}
\hline & Sample & Total polyphenols \\
\hline 1 & Athyrium filix-femina & $915.53 \pm 25.16$ \\
2 & Dryopteris affinis & $887 \pm 108.16$ \\
3 & Dryopterisfilix-mas & $2340 \pm 85.44$ \\
\hline
\end{tabular}


Tab. 3. Antimicrobial activity of methanolic extract against some pathogenic bacteria

\begin{tabular}{|c|c|c|c|c|c|c|c|c|c|c|}
\hline \multirow[t]{2}{*}{ Sample } & \multicolumn{2}{|c|}{$\begin{array}{l}\text { Escherichia coli } \\
\text { ATCC } 25922 \\
2 \times 10^{10} \mathrm{cfu} / \mathrm{cm}^{3}\end{array}$} & \multicolumn{2}{|c|}{$\begin{array}{c}\text { Pseudomonas aeruginosa } \\
\text { NBJMCC } 1390 \\
1 \times 10^{13} \mathrm{cfu} / \mathrm{cm}^{3}\end{array}$} & \multicolumn{2}{|c|}{$\begin{array}{l}\text { Salmonella abony } \\
1.6 \times 10^{10} \mathrm{cfu} / \mathrm{cm}^{3}\end{array}$} & \multicolumn{2}{|c|}{$\begin{array}{c}\text { Staphylococcus aureus } \\
\text { ATCC } 25093 \\
1 \times 10^{13} \mathrm{cfu} / \mathrm{cm}^{3}\end{array}$} & \multicolumn{2}{|c|}{$\begin{array}{c}\text { Enterococcus } \\
\text { faecalis } \\
1.7 \times 10^{12} \mathrm{cfu} / \mathrm{cm}^{3}\end{array}$} \\
\hline & $\mathrm{IZ}$ & MIC & $\mathrm{IZ}$ & MIC & $\mathrm{IZ}$ & MIC & $\mathrm{IZ}$ & MIC & $\mathrm{IZ}$ & MIC \\
\hline Athyrium filix-femina & $8.00 \pm 1.41$ & $>600$ & $8.50 \pm 0.70$ & $>600$ & $8.50 \pm 0.70$ & $>60$ & $7.00 \pm 0.0$ & $>600$ & $7.00 \pm 0.0$ & $>600$ \\
\hline Dryopteris affinis & $8.00 \pm 0.0$ & $>600$ & $9.00 \pm 1.41$ & $>600$ & $9.00 \pm 1.41$ & $>60$ & $10.00 \pm 1.41$ & 600 & $10.50 \pm 0,70$ & $>60$ \\
\hline Dryopteris filix-mas & $10.00 \pm 0.0$ & 60 & $8.00 \pm 0.0$ & $>600$ & $9.00 \pm 0.0$ & 60 & $10.00 \pm 0.0$ & 600 & $9.00 \pm 1.41$ & 60 \\
\hline
\end{tabular}

IZ-inhibition zone (mm); MIC-minimum inhibitory concentration (ppm); cfu-colony forming units

Tab. 4. Antimicrobial activity of methanolic extract against some saprophytic microorganisms

\begin{tabular}{|c|c|c|c|c|c|c|c|c|c|c|}
\hline \multirow[t]{2}{*}{ Sample } & \multicolumn{2}{|c|}{$\begin{array}{c}\text { Brevibacterium flavum } \\
\text { ATCC } 14067 \\
3.610^{13} \mathrm{cfu} / \mathrm{cm}^{3}\end{array}$} & \multicolumn{2}{|c|}{$\begin{array}{c}\text { Sarcina sp., } \\
1.7 \cdot 10^{10} \mathrm{cfu} / \mathrm{cm} 3\end{array}$} & \multicolumn{2}{|c|}{$\begin{array}{l}\text { Bacillus cereus } \\
\text { ATCC } 1390 \\
1.4 \cdot 10^{11} \mathrm{cfu} / \mathrm{cm}^{3}\end{array}$} & \multicolumn{2}{|c|}{$\begin{array}{c}\text { Saccharomyces } \\
\text { cerevisiae, } \\
3.9 \cdot 10^{7} \mathrm{cfu} / \mathrm{cm}^{3}\end{array}$} & \multicolumn{2}{|c|}{$\begin{array}{c}\text { Aspergillus niger } \\
1 \cdot 10^{5} \mathrm{cfu} / \mathrm{cm}^{3}\end{array}$} \\
\hline & $\mathrm{IZ}$ & MIC & $\mathrm{IZ}$ & MIC & $\mathrm{IZ}$ & MIC & $\mathrm{IZ}$ & MIC & $\mathrm{IZ}$ & MIC \\
\hline Athyrium filix-femina & $8.00 \pm 0.0$ & $>600$ & 0 & 0 & $9.00 \pm 0.0$ & 600 & $10.00 \pm 0.0$ & 600 & $8.00 \pm 0.0$ & $>600$ \\
\hline Dryopteris affinis & $9.50 \pm 0.70$ & 600 & $9.00 \pm 0.0$ & $>600$ & $10.50 \pm 0.70$ & 600 & $10.50 \pm 0.70$ & 600 & $9.00 \pm 1.41$ & 600 \\
\hline Dryopteris filix-mas & $9.00 \pm 1.41$ & 600 & $8.00 \pm 0.0$ & $>600$ & $10.50 \pm 0.70$ & 600 & $12.00 \pm 0.0$ & $>60$ & $8.00 \pm 0.0$ & $>600$ \\
\hline
\end{tabular}

IZ-inhibition zone (mm); MIC-minimum inhibitory concentration (ppm); cfu-colony forming units

and Staphyllococcus aureus. Different researches showed that the strong antibiotic activities of different ferns from Dryopteris genus. D. crassirhizoma and D. flix-mas can be used against Methicillin resistant $S$. aureus (Lee et al., 2009), and D. cochleata against gram positive and negative bacteria and fungi (Banerjee and Sen, 1980). The aqueous extract obtained from leaves of $D$. cochleata was effective against E. coli and Salmonella typhi, while the alcoholic extract was effective against Agrobacterium tumefaciens, $E$. coli and Salmonella typhi (Parihar et al., 2010).D.crassirhizoma is patented as an anti-tooth decay substance because of its high activity against Streptococcus in Korea.

The extracts obtained from some ferns could be utilized as effective natural cosmetic ingredients for the treatment or prevention of acne (Lee and Shin, 2011); some Dryopteris spp. exhibit strong antimicrobial activities against Propionibacterium acnes, known as a main factor of acne (pimple) (Kim et al., 2006).

\section{Conclusions}

The methanolic extracts obtained from leaves of Atbyrium filix-femina, Dryopteris affinis and D. filix-mas ferns have shown a good antioxidant activity. A positive correlation was obtained between the antioxidant activity and the total phenolic compounds. These plants could be a good source of natural antioxidants. The best antimicrobial activity was demostrated by the $D$. filix-mas extract. The tested ferns could be used as cosmetic ingredients, as preservatives in food or in antimicrobial therapy.

\section{Acknowledgements}

The work was financially supported by the project POSDRU/89/1.5/S/52432 from 1.04.2010-Institutional organization of a postdoctoral school of national interest "Applied biotechnology with impact in the Romanian economy"; the project was co-funded by the EU Social Fund within the Sectorial Operational Programme 20072013 for Human Resources Development.

\section{References}

Banerjee RD, Sen SP (1980). Antibiotic activity of pteridophytes. Econ Bot 34:284-298.

Cai Y, Luo Q, Sun M, Corke H (2004). Antioxidant activity and phenolic compounds of 112 traditional Chinese medicinal plants associated with anticancer. Life Sci 74:2157-2184.

Chang HC, Huang GJ, Agrawal DC, Kuo CL, Wu CR, Tsay HS (2007). Antioxidant activities and polyphenol contents of six folk medicinal ferns used as "Gusuibu". Bot Stud 48:397-406.

Chang HC, Gupta SK., Tasay HS (2011). Studies on Folk Medicinal Fern: An Example of "Gu-Sui-Bu", 285-304 p. In: Fernández H, Kumar A, Revilla MA (Eds.). Working with Ferns, Issues and Applications, Springer, New York, Dordrecht, Heidelberg, London.

Ciocârlan V (2009). Illustrated Flora of Romania, Pteridophyta et Spermatophyta. $3^{\text {th }}$. Ed Ceres, Bucharest.

Katalinic V, Milos M, Kulisic T, Jukic M. (2006). Screening of 70 medicinal plants for antioxidant capacity and total phenols. Food Chem 94:550-557. 
Kim HJ, Lim HW, Choi SW, Yoon CS (2006). Antimicrobial effect of ethanol extract of Dryopteris crassirbizoma Nakai on Propionibacterium acnes. J Soc Cosmet Sci Korea 32:201208.

Kiselova Y, Ivanova D, Chervenkov T, Gerova D, Galunska B, Yankova T (2006). Correlation between the in vitro antioxidant activity and polyphenol content of aqueous extracts from bulgarian herbs. Phytother Res 20(11):961965.

Kratchanova M, Denev P, Ciz M, Lojek A, Mihailov A (2010). Evaluation of antioxidant activity of medicinal plants containing polyphenol compounds. Comparison of two extraction systems Acta Biochem Pol 57(2):229-234.

Lee HB, Kim JC, Lee SM (2009). Antibacterial activity of two phloroglucinols, flavaspidic acids $\mathrm{AB}$ and $\mathrm{PB}$, from Dryopteris crassirhizoma. Arch Pharm Res 32:655-659.

Lee CH, Shin SL (2011). Functional Activities of Ferns for Human Health, 347-359 p. In: Fernández H, Kumar A, Revilla MA (Eds.). Working with Ferns, Issues and Applications, Springer, New York, Dordrecht, Heidelberg, London.

Maizura M, Aminah A, Wan Aida WM (2011). Total phenolic content and antioxidant activity of kesum (Polygonum minus), ginger (Zingiber officinale) and turmeric (Curcuma longa) extract. I Food Res J 18:529-534.

Mubashir S, Shah WA (2011). Phytochemical and pharmacological review profile of Adiantum venustum. I J Pharm Tech Res 3(2):827-830.

Ninfali P, Mea G, Giorgini S, Rocchi M, Bacchiocca M (2005) Antioxidant capacity of vegetables, spices and dressings relevant to nutrition. Br J Nutr 93:257-266.

Ou B, Huag D, Hampsch-Woodill M, Prior RL (2001). Development and validation of an improved oxygen radical absorbance capacity assay using fluorescein as the fluorescent probe. J Agric Food Chem 49:4619-4626.

Parihar P, Parihar L, Bohra A (2010). In vitro antibacterial activity of fronds (leaves) of some important pteridophytes. J Microbiol Antimicrobials 2:19-22.

Rice-Evans CA, Miller NJ, Paganga G (1997). Antioxidant properties of phenolic compounds. Trends Plant Sci 2:152159.
Shan B, Cai YZ, Sun M, Corke H (2005). Antioxidant capacity of 26 spice extracts and characterization of their phenolic constituents. J Agric Food Chem 53:7749-7759.

Shin SL (2010). Functional components and biological activities of Pteridophytes as healthy biomaterials. Chungbuk National University, Cheongju, Korea, PhD Diss.

Singleton VL, Rossi JA (1965). Colorimetry of total phenolics with phosphomolybdic-phosphotungstic acid reagents. Am J Enol Vitic 16 (3):144-158.

Souri E, Amin G, Farsam H, Tehrani M (2008). Screening of antioxidant activity and phenolic content of 24 medicinal plant extracts. Daru 16(2):83-87.

Uddin MG, Mirza MM, Pasha MK (1998). The medicinal uses of pteridophytes of Bangladesh. Bangladesh J Plant Taxon 5(2):29-41.

Vasco C, Ruales J, Eldin AK (2008). Total phenolic compounds and antioxidant capacities of major fruits from Ecuador. Food Chem 111:816-823.

Wojcikowski K, Stevenson L, Leach D, Wohlmuth H, Gobe G (2007). Antioxidant capacity of 55 medicinal herbs traditionally used to treat the urinary system: a comparison using a sequential three-solvent extraction process. J Alt Compl Med 13:103-110.

Wojdyło A, Oszmiansky J, Czemerys R (2007). Antioxidant activity and phenolic compounds in 32 selected herbs. Food Chem 105:940-949.

Wong C, Li H, Cheng K, Chen F (2006). A systematic survey of antioxidant activity of 30 Chinese medicinal plants using the ferric reducing antioxidant power assay. Food Chem 97:705-711.

Wu CQ, Chen F, Wang X, Kim HJ, He GQ, Haley-Zitlin V, Huang G (2006). Antioxidant constituents in feverfew (Tanacetum parthenium) extract and their chromatographic quantification. Food Chem 96:220-227.

Zheng W, Wang SY (2001). Antioxidant activity and phenolic compounds in selected herbs. J Agr Food Chem 49(11):5165-5170. 